\title{
Pertanggungjawaban Negara Dalam Kegiatan Komersiil Ruang Angkasa Yang Dilakukan Oleh Perusahaan Swasta
}

\section{Sri Wartini}

\begin{abstract}
Commercial space activities conducted by private company may raise legal problems which relate to state responsibility. State Responsibility can be embodied in the national regulation, national policies and effective control of commercial space activities by the government, such as permit system with specific and private company to participate on the commercial space activities. Therefore, the company is able to fulfil its responsibility and liability if its activities cause disadvantage to the third parties.
\end{abstract}

\section{Pendahuluan}

Komersialisasi ruang angkasa termasuk bulan dan obyek-obyek ruang angkasa yang lainnya semakin marak akhir-akhir ini. Hal ini merupakan konsekuensi logis dari pesatnya perkembangan teknologi ruang angkasa. Pada awal mulanya, kegiatan komersial ruang angkasa hanya dilakukan deh negara, akan tetapi dalam perkembangannya banyak perusahaan swasta yang berpartisipasi dalam kegiatan ini, khususnya di negara-negara maju. Kompetisi yang ketat terjadi antara Amerika Serikat, Eropa dan China, bahkan China dapat menawarkan harga yang paling rendah diantara competitor yang lain, misalnya dalam penyediaan fasilitas peluncuran.'

Pemanfaatan ruang angkasa untuk tujuan komersiil ini merupakan suatu kegiatan yang dilakukan baik oleh badan-badan pemerintah maupun swasta yang bertujuan untuk memperoleh keuntungan secara ekonomis. Adapun kegiatan-kegiatan komersiil yang dilakukan antara lain peluncuran satelit komunikasi, penginderaan jarak jauh, sistem transportasi ruang angkasa, pertambangan, dan penyiaran langsung melalui satelit. ${ }^{2}$ Dari berbagai kegiatan komersil tersebut, komunikasi, penginderaan jarak jauh dan sistem transportasi khususnya wahana peluncuran, telah bergerak maju mendahului aktivitas yang lain. ${ }^{3}$ Jasa komunikasi melaului satelit sangat dibutuhkan oleh mereka yang bergerak dibidang keuangan, penerbitan, hiburan, pengolahan data, hukum dan periklanan. ${ }^{4}$

'Dieriks Verschoor, An Introduction to Space Law, (Boston, Kluwer Law and Taxation Publishers, 1993), him. 98.

${ }^{2}$ Wahyuni Bahar, Pertanggungjawaban Negara Terhadap Aktivitas Komersial di RuangAngkasa, dalam E. Saefullah Wiradipradja dan Mieke Komar Kantaatmadja (Editor ), Hukum Angkasa dan Perkembangannya, (Bandung, Cv Remaja Karya, 1988), hlm. 173.

${ }^{3}$ Juajir Sumardi, Hukum Ruang Angkasa Suatu Pengantar, (Jakarta, PT Pradnya Paramita, 1996), hlm. 48.

$4 \mathrm{lbid}, 49$. 
Pemanfaatan sumber daya ruang angkasa untuk kepentingan komersil sampai saat ini masih didominasi oleh negara-negara maju, walupun menurut Space Treaty ruang angkasa merupakan warisan bersama umat manusia (common heritage of mankind) dimana setiap negara berhak untuk melakukan ekploitasi di ruang angkasa, dan tidak satu negara pun di dunia ini yang berhak untuk menyatakan kedaulatannya di ruang angkasa. ${ }^{5}$ Akan tetapi negara berkembang belum dapat menggunakan haknya karena keterbatasan teknologi, finansial dan human resourses. Sedangkan dampak kegiatan ruang angkasa seperti radiasi yang diakibatkan oleh jatuhnya pesawat ruang angkasa tidak hanya akan diderita oleh negara maju, tetapi juga diderita oleh negara berkembang. Dengan demikian perlu adanya suatu perlindungan hukum bagi negaranegara berkembang yang merupakan korban potensial dari kegiatan ruang angkasa, apalagi dengan terlibatnya pihak swasta dalam kegiatan komersiil, maka kuantitas kegiatan semakin bertambah dan tentu saja potensi reikonya juga semakin bertambah besar. Akan tetapi bila dilihat ketentuan internasional yang mengatur kegiatan ruang angkasa sebagaimana yang tertuang dalam Space Treaty maupun Liability Convention tahun 1972 hanya mengatur kegiatan yang dilakukan oleh negara, sedangkan kegiatan yang dilakukan oleh perusahaan swasta belum diatur secara jelas.

Kegiatan komersil ruang angkasa sama dengan kegiatan ruang angkasa lain yang diatur dalam Space Treaty, sehingga kegiatan tersebut juaga merupakan obyek yang diatur dalam Space Treaty. Semua negara yang telah meratifikasi terikat oleh ketentuan yang dimuat dalam Space Treaty. Istilah komersialisasi ruang angkasa memang tidak secara jelas di muat dalam Outer Space Treaty, akan tetapi secara umum kegiatan komersialisasi ini dapat diartikan segala macam bentuk aktivitas yang berhubungan dengan ruang angkasa untuk memperoleh keuntungan. ${ }^{6}$

Sebelum lebih mendetail membahas masalah komersialisasi ruang angkasa, kiranya perlu diklarifikasi lebih dulu konsep " komersialisasi“. Pada saat ini ada kecenderungan yang membingungkan antara komersialisasi dan privatisasi. Komersialisasi berarti "menjual" (sale), adanya unsur keuntungan, karena adanya transfer barang dan jasa dari penjual kepada pembeli. Subyek dalam komersialisasi tidak hanya perusahaan swasta, tetapi juga negara dan Organisasi Internasional. Sedangkan swastanisasi (privatization), berarti adanya perubahan kepemilikan dan operasional dari negara kepada pihak swasta. ${ }^{7}$ Secara konseptual, komersialisasi dan privatisasi adalah dua hal yang berbeda. Oleh karena itu, harus dipahami secara jelas dalam rangka untuk perlindungan keamanan nasional dan pelaksanaan tanggung jawap negara terhadap kegiatan ruang angkasa yang dilakukan oleh pihak swasta.

Komersialisasi ruang angkasa yang melibatkan sektor swasta semakin meningkat, terutama di negara-negara maju, namun demikian perangkat hukum yang mengaturnya

${ }^{5}$ Martin Dixon, Intemational Law, (London, Blackstone Press Limited, 1996), hlm.150.

6Wahyuni Bahar, Pertanggungjawaban Negara Terhadap... Op.Cit., hlm. 165.

${ }^{7}$ Committee and Commerce, Science and Transportation, US Senate, 1983, " Policy and Legal Issues Involved in the Coomercialization of Space “, hlm. 23. 
belum tersedia. Hal ini dapat menimbulkan suatu permasalahan hukum tersendisi dalam kegiatan ruang angkasa. Kegiatan ruang angkasa yang diatur dalam hukum ruang angkasa subjeknya adalah negara, sedangkan kegiatan yang dilakukan oleh perusahaan swasta tidak diatur secara jelas. Keterlibatan perusahaan swasta dalam kegiatan ruang angkasa tidak pernah terjadi tanpa adanya ijin dari negara. Oleh karena itu peranan negara dalam mengatur kegiatan ruang angkasa yang dilakukan oleh perusahaan swasta ini sangat penting.

Perusahaan swasta yang melakukan kegiatan komersiil di ruang angkasa tentunya harus mentaati ketentuan hukum nasional negara yang bersangkutan, selain perusahaan tersebut juga harus mentaati ketentuanketentuan internasional yang berlaku dalam kegiatan ruang angkasa, karena kegiatan ini sangat bersinggungan dengan kepentingan internasional. Keterlibatan pihak swasta dapat secara langsung maupun secara tidak langsung, seperti halnya dalam bentuk investasi. Dengan bertambahnya pelaku dalam kegiatan komersiil ruang angkasa, apakah ketentuan yang ada sudah cukup memadai untuk mengatur kegiatan tersebut, terutama dengan terlibatnya sector swasta, karena dalam kegiatan ini menyangkut tanggung jawab negara.

Outer Space Treaty dapat dikatakan sebagai tulang punggung kegiatan ruang angkasa. ${ }^{8}$ Akan tetapi, ketika Outer Space disepakati dan berlaku, tidak satu negarapun yang memikirkan tentang keterlibatan langsung sektor swasta dalam kegiatan ruang angkasa. Oleh karena itu, perlu untuk melakukan kajian terhadap ketentuan hukum ruang angkasa yang ada. Penulis tertarik untuk menganalisa bagaimana implikasi hukum yang muncul dengan adanya kegiatan ruang angkasa yang dilakukan oleh perusahaan swasta terutama yang berkaitan dengan tanggung jawab negara dalam kegiatan ruang angkasa yang dilakukan oleh perusahaan swasta.

\section{Ketentuan Internasional Terhadap Kegiatan Komersiil Ruang Angkasa Oleh Perusahaan Swasta}

Keterbatasan hukum ruang angkasa dalam mengatur komersialisasi ruang angkasa di lain pihak memberikan keluasaan kepada negara untuk menentukan kebijakan dan pengaturan di negaranya. Sesuai dengan teori hukum internasional publik, pelaksanaan yurisdiksi sebagai suatu aspek khusus dari kerdaulatan meliputi tindakan-tindakan di bidang administif, legislatif, dan yudikatif. ${ }^{9}$ Berkaitan dengan aktivitas komersial di ruang angkasa, suatu kecenderungan kuat dewasa ini adalah semakin banyak negara yang mengatur pelaksanaan yurisdiksinya pada kegiatan komersiil ruang angkasa yang dilakukan oleh perusahaan swasta dalam bentuk kebijakan nasional dan perundangundangan nasional.

Sebagai contoh Amerika Serikat, salah satu usaha pemerintah Amerika Serikat untuk mengatur kegiatan ruang angkasa yang dilakukan oleh perusahaan swasta ( privat company ) ialah dengan disetujuinya Land Remote Sensing Commersialization Act oleh

\footnotetext{
${ }^{8}$ Dieriks Verschoor, Op.Cit., him.21.

${ }^{9}$ Martin Dixon, Op.Cit., hilm. 125-126.
} 
Kongres pada tahun $1984 .{ }^{10}$ Dalam pertimbangannya Kongres menegaskan bahwa kepentingan nasional Amerika Serikat adalah mempertahankan kepemimpinan Amerika Serikat dalam aktivitas penginderaan jarak jauh untuk keperiuan tersebut dijamin keterlibatan swasta secara kompetitif dan berdasarkan mekanisme pasar. Kerja sama pemerintah dan industri swasta diadakan untuk mengatasi kesulitan pihak swasta yang menghadapi resiko tinggi dan biaya besar. Bagaimanapun, kongres menegaskan bahwa kerjasama ini diadakan dengan membatasi bantuan dan pengaturan pemerintah federal serta membuka lebar persaingan di sektor swasta."

\section{a. Legalitas Kegiatan Ruang Angkasa oleh Perusahaan Swasta Dalam Hukum Internasional}

Walaupun artikel I Outer Space Treaty hanya menjamin adanya hak yang sama untuk negara untuk mengaksess, mengeksploitasi dan memanfaatkan ruang angkasa, tetapi bukan berarti tidak membolehkan keterlibatan sektor swasta dalam kegiatan ruang angkasa. $\mathrm{Hal}$ ini tercermin dalam ketentuan Outer Space Treaty pasal VI. Dalam pasal ini disebutkan bahwa dalam kaitannya dengan pertanggungjawaban internasional, negara bertanggung jawab atas kegiatan ruang angkasa yang dilakukan oleh sektor swasta, dan negaralah yang berhak memberikan ijin dan berkewajiban untuk mengawasi kegiatan ruang angkasa yang dilakukan oleh sector swasta.

Sekalipun sektor swasta bukanlah subjek langsung yang dapat melaksankan kegiatan ruang angkasa, apakah kegiatan komersiil ruang angkasa dapat dilakukan oleh pihak swasta ? Dalam Space Treaty, pengertian " exploration and use "digunakan dalam pengertian ekonomi dan pengetahuan yang luas. Sedangkan dalam Moon Agreement, pegertian "exploration "diartikan sebagai pengertian yang menimbulkan kepentingan ekonomi. ${ }^{12}$ Namun demikian sebaiknya dianalisa, apakah kegiatan komersial ruang angkasa sesuai dengan prinsip kepentingan bersama (common interest)yang dikarakterisasikan sebagai kegiatan untuk pelayanan publik intemasional.

Prinsip kepentingan bersama (common interest $)^{13}$ yang tertuang dalam artikel I paragraph 1 Outer Space Treaty menyatakan bahwa ekplorasi dan penggunaan ruang angkasa harus dilaksanakan untuk keuntungan dan kepentingan seluruh umat manusia, hal ini sesuai dengan prinsip ruang angkasa sebagai warisan bersama umat manusia (common heritage of mankind) ) $^{14}$ dimana semua negara berhak untuk memanfaatkan ruang angkasa, namun tidak ada satu negara pun yang memiliki kedaulatan di ruang angksa.

Berdasarkan kebijaksanaan dan pandangan hukum, dapat diartikan bahwa

${ }^{10}$ Diederiks Verschoor, Op.Cit., hlm.100.

"Wahyuni Bahar, Perlanggungjawaban Negara Terhadap ... Op.Cit., hlm. 173.

${ }^{12}$ Pasal IV The Moon Agreement

${ }^{13}$ B. Nagy, Common Heritage of Mankind : The Status of Future Generations, (Proceedings 31 st Colloquium,Bangalore, 1988), hlm. 319.

"Williams, The Exploitation and Use of Natural Resourcesin the New Law of the Sea and the Law of Outer Space, (Proceedings of the 29th Colloquium on the Law of Outer Space, 1988), hilm. 198. 
dalam pemanfaatan ruang angkasa seharusnya dapat menjamin adanya pemanfaatan yang adil terhadap ruang angkasa (equitable utilization of outer space) dan memberikan perlindungan hukum kepada negara atas pelanggaran yang dilakukan oleh negara lain yang melakukan kegiatan ruang angkasa. Menjamin keadilan pemanfaatan ruang angkasa berarti "ruang angkasa memang benar-benar digunakan untuk untuk kepentingan semua negara dan bukan hanya untuk kepentingan negara secara individual atau sekelompok negara saja".

Untuk menentukan apakah kegiatan komersiil ruang angkasa sesuai dengan ketentuan hukum yang berlaku atau tidak tergantung kepada pertimbangan apakah prinsip kepentingan bersama (common interest ) merupakan suatu kewajiban yang mengikat yang tertuang dalam perjanjian internasional atau hanya merupakan suatu deklarasi yang tidak memiliki kekuatan mengikat? Dalam prinsip ini dapat dinterpretasikan bahwa kegiatan komersil di ruang angkasa hanya akan diterima kalau menjamin adanya keuntungan bagi seluruh umat manusia.

Prinsip kepentingan bersama tidak harus diinterpretasikan sebagai suatu larangan terhadap kegiatan komersill di ruang angkasa oleh sektor swasta. Hal ini dapat ditemukan dalam ketentuan pasal VI dan IX Space Treaty, secara jelas menunjukkan bahwa dijinkannya partisipasi perusahaan swasta dalam kegiatan komersill ruang angkasa. ${ }^{15}$ Selain itu, kegiatan komersil di ruang angkasa oleh perusahaan swasta akan memungkinkan bagi negara-negara kecil yang kurang mempunyai dana dan teknologi untuk kegiatan tersebut berpartisipasi dalam kegiatan komersill ruang angkasa. Misalnya dengan adanya investasi yang dilakukan oleh Multinasional Corporation di suatu negara.

Berkaitan dengan pemanfaatan ruang angkasa untuk kegiatan komersiil, justifikasi yang dapat dikemukakan ialah bahwa prinsip kepentingan bersama (common interest), mungkin bermanfaat, karena karakternya yang umum, yang berkaitan dengan permasalahanpermasalahan perubahan-perubahan yang komplek dalam masyarakat internasional. Prinsip kepentingan bersama sesuai dengan prinsip kebebasan ruang angkasa. ${ }^{16}$ Prinsip ini membatasi kebebasan ruang angkasa sedemikian rupa untuk menghindari adanya pelanggaran hak dalam pemanfaatan ruang angkasa.

Dapat ditariksuatupengertian bahwa prinsip kepentingan bersama (common concem) adalah suatu aturan yang mengikat dan kegiatan komersiil ruang angkasa sesuai dengan prinsip ini sepanjang aktivitas tersebut memberikan kontribusi terhadap peningkatan kesejahteraan sosial dan dengan melalui peningkatan standar hidup, walaupun substansinya adalah merupakan pengalihan keuntungan produk dan jasa.

\section{b. Ketentuan Nasional Kegiatan Ruang Angkasa Oleh Perusahaan Swasta}

Keterbatasan hukum ruang angkasa dalam mengatur komersialisasi ruang angkasa dilain pihak memberikan keleluasaan bagi negara untuk menentukan

\footnotetext{
${ }^{15}$ Pasal VI dan IX Space Treaty 1967.

${ }^{16}$ Pasal I Space Treaty 1967.
} 
kebijakan dan pengaturan di negaranya. Berdasarkan teori hukum internasional publik, negara memiliki yurisdiksi baik dalam bidang eksekutif, legislatif dan yudikatif. ${ }^{17}$ Dalam praktek negara yang mengijinkan pihak swasta untuk berpartisipasi dalam kegiatan nasionalnya melaksanakan yurisdiksinya berupa pembentukan kebijakan nasional dan Undang-Undang Nasional tentang kegiatan ruang angkasa. Sebagai salah satu contoh misalnya Amerika Serikat. Di Amerika kalau dilihat tentang kebijakan pemerintah Amerika dalam kegiatan ruang angkasa diatur dalam NASA Act 1984. Dalam pertimbangannya, Kongres menegaskan bahwa kepentingan nasional AS adalah mempertahankan kepemimpinan AS dalam aktivitas penginderaan jauh, untuk keperluan tersebut harus dijamin keterlibatan pihak swasta secara kompetitif dan berdasarkan mekanisme pasar. Kerja sama pemerintah swasta dilakukan untuk mengatasi kesulitan pihak swasta yang menghadapi resiko tinggi dan biaya besar ${ }^{18}$ Selain itu kebijakan Nasional Amerika Serikat juga tertuang dalam US Space Transportation Policy tahun 2004 dan National Sapce Policy tahun 1996. ${ }^{19}$

Tujuan utama LRSC Act adalah meletakkan kerangka komersialisasi ruang angkasa secara bertahap. Menteri perdagangan ditugaskan untuk mengadakan perjanjian dengan pihak swasta dalam pengembangan, pengoperasian, dan pemasaran data. Proses pengalihan kepada swasta, yang baru boleh dilaksanakan setelah masa transisi 6 tahun, harus dilakukan secara terbuka tanpa ada prioritas walaupun tidak tertutup kemungkinan pemerintah memberikan bantuan dalam bentuk pinjaman, dan lain-lain.

Ketentuan lain yang juga dilakukan oleh USA ialah diundangkannya Commercial Space Launch Act (CSL) Act. Dalam udangundang ini memuat suatu sistem pengaturan yang komprehensif meliputi penetapan kebijakan, koordinasi diantara berbagai badan pemerintah yang berkaitan dengan prosedur permohonan dan syarat-syarat perizinan serta penegakan hukum. Sedangkan untuk masalah tanggung jawab (liability) CLS Act mewajibkan warga negara yang meluncurkan atau mengoperasikan tempat peluncuran untuk menutup asuransi tanggung jawab. Kewajiban ini dimaksudkan untuk memenuhi kewajiban internasional AS, sebagaimana diatur dalam Liability Convention.

Perundang-undangan lain yang juga dikeluarkan Amerika untuk mengatur kegiatan komersiil ruang angkasa ialah Commercial Space Act tahun 1998, Commercial Space Transportation Competitiveness Act tahun $2000 .^{20}$ Dalam kedua Undang-undang tersebut menegaskan kembali tentang kewajiban asuransi yang harus ditutup oleh pihak-pihak yang melaksanakan kegiatan komersil di ruang angkasa. Hal ini dimaksudkan untuk menjamin pelaksaan tanggungjawab atas kerugian yang diderita pihak ketiga.

17 John O'Brien, Op.Cit., him. 227.

${ }^{18}$ Diederiks Verschoor, Op.Cit, him. 100-101.

${ }^{19} \mathrm{http}$ ://ast.faa.gor/poli-legil. Associate Administrator for Commercial Space Transportation Policy and and Legislation, diakses pada tanggal 24 Maret 2005

${ }^{20} \mathrm{lbid}$. 
Dengan adanya kegiatan komersiil ruang angkasa yang dilakukan oleh sektor swasta di suatu negara, maka Space Treaty telah memberikan mandat kepada negara untuk mengatur kegiatan ruang angkasa di wilayah nasional suatu negara baik yang dilakukan oleh pemerintah maupun yang dilakukan oleh sektor swasta. Ada dua pilihan yang dapat dilakukan oleh negara berdasarkan kekuasaan yang dimilikinya yaitu : pertama, mengijinkan sektor swasta secara langsung ikut serta dalam kegiatan ruang angkasa atau melarangnya sama sekali, kedua, negara membuat suatu mekanisme pengawasan untuk menghindari kerusakan yang disebabkan oleh kegiatan sektor swasta dan mencegah terjadinya tanggung jawab negara secara praktis.

Kalau pilihan pertama yang dipilih akan terjadi pelanggaran terhadap hak kebebasan untuk memanfaatkan hak milik, dan hal tersebut bukanlah merupakan pilihan yang tepat untuk pertumbuhan ekonomi yang berbasis pada sektor swasta. Sedangkan untuk pilihan yang kedua hanya akan dapat dilaksanakan kalau ditindaklanjuti dengan adanya kebijakan nasional dan perundang-undangan nasional yang merupakan pengimplementasian Konvensi Internasional, misalnya Undang-Undang tentang Komersialisasi Ruang Angkasa sebagaimana yang diundangkan oleh Amerika Serikat.

Dalam rangka untuk melaksanakan kewajiban yang tertuang dalam Space Treaty, negara sangat perlu untuk mengundangkan ketentuan/peraturan tentang kegiatan komersiil di ruang angkasa untuk menjamin bahwa negara melakukan pengawasan terhadap kegiatan ruang angkasa baik yang dilakukan oleh pemerintah maupun yang dilakukan oleh sektor swasta. Selain itu, dalam menjamin keamanan dan keselamatan kegiatan ruang angkasa perlu ditentukan adanya standar kualitas internasional (International Quality Standard), karena kalau masing-masing negara menentukan sendiri kualitas standarnya, maka akan menimbulkan suatu permasalahan, dan hal tersebut akan berbahaya sekali bagi keselamatan kegiatan komersiial. Hal ini dapat dicegah dengan membentuk suatu perjanjian internasional yang mengatur mengenai standar internasional tersebut.

\section{c. Yurisdiksi Negara Terhadap Kegiatan Ruang Angkasa yang Dilakukan oleh Perusahaan Swasta}

Kemajuan teknologi telah memungkinkan perluasan aktivitas negara ke wilayah di luar kedaulatan dan jurisdiksi negara seperti ruang angkasa. Ketika manusia memulai menjelajahi ruang angkasa, para ahli hukum pun segera bergerak untuk menghindarkan terjadinya kekosongan hukum. Hal yang menarik adalah hukum ruang angkasa sejak awal pembentukannya telah berusaha meliputi perkembangan dimasa depan, seperti misalnya ketentuan tentang keterlibatan sektor swasta dalam kegiatan ruang angkasa, walaupun tidak secara detail diatur mengenai keterlibatan sektor swasta. ${ }^{21}$

Pada awal mulanya kegiatan ruang angkasa hanya dilakukan oleh negara dan jenis kegiatan yang dilakukannya pun tidak bersifat komersiil, seperti misalnya riset ilmiah. Akan tetapi pada perkembangannya kegiatan ruang angkasa meliputi juga kegiatan

21 Pasal VI Space Treaty 1967. 
komersil, bahkan yang awal mulanya kegiatan ruang angkasa hanya dilakukan oleh negara, sekarang sektor swasta pun juga berpartisipasi dalam kegiatan ruang angkasa, karena bisnis ini memang sangat menguntungkan disamping resikonya yang cukup besar.

Ketentuan Space Treaty yang berkaitan dengan aktivitas komersil dewasa ini dapat ditemukan dalam pasal VI. Dalam pasal ini disebutkan bahwa negara bertanggung jawab atas kegiatan ruang angkasa baik yang dilakukan oleh negara maupun yang dilakukan oleh sektor swasta. ${ }^{22}$ Sekalipun kegiatan tersebut belum diatur secara mendetail, sehingga memberikan kesempatan kepada masing-masing negara untuk mengatur sesuai dengan kebijakan nasionalnya terhadap kegiatan komersill ruang angkasa.

Masalah tanggung jawab negara ini berkaitan erat dengan masalah jurisdiksi negara terhadap objek yang diluncurkan di ruang angkasa, sehingga jika kegiatan komersiil tersebut dilakukan oleh sektor swasta, maka yang memiliki jurisdiksi atas objek ruang angkasa tersebut adalah negara. ${ }^{23}$ Pengertian jurisdiksi berarti hak dan authoritas untuk melaksanakan kewenangannya bukan hanya dalam bidang hukum, tetapi juga juga kekuasaan legislatif dan eksekutif yang berkaitan dengan awak pesawat dan objek ruang angkasa. Jurisdiksi merupakan manifestasi dari kedaulatan.

Jurisdiksi dan pengawasan negara pendaftar terbatas pada objek yang diluncurkan ke ruang angkasa beserta personilnya. ${ }^{24}$ Berdasarkan Space Treaty pasal Vl, suatu negara yang warga negaranya melaksanakan kegiatan ruang angkasa memiliki yurisdiksi dan wajib bertanggung jawab secara internasional untuk menjamin bahwa aktivitas yang dilakukan oleh warga negaranya sesuai dengan ketentuan Space Treaty. Walaupun secara umum, suatu negara tidak berkewajiban untuk mengawasi kegiatan individual di luar jurisdiksi negaranya. Namun demikian, adalah memungkinkan untuk menggambarkan kewajiban negara dalam mengawasi kegiatan individu di luar jurisdiksi negaranya berdasarkan konvensi. Misalnya, dalam Lotus Case, pengertian jurisdiksi hanya meliputi jurisdiksi teritorial, jurisdiksi ini tidak dapat dilaksanakan oleh suatu negara di luar yurisdiksinya, kecuali diperoleh berdasarkan hukum kebiasaan internasional dan konvensi. ${ }^{25}$ Artikel VI Space Treaty merupakan contoh bahwa suatu negara bertanggung jawab secara internasional untuk menjamin aktivitas ruang angkasa yang dilakukan di wilayah negaranya sesuai dengan ketentuan Space Treaty, bahkan di luar yurisdiksi negara.

Berdasarkan artikel III Space Treaty menyatakan bahwa kegiatan ruang angkasa yang dilakukan oleh negara harus sesuai dengan hukum internasional, termasuk Piagam PBB. Artikel ini merefleksikan adanya suatu kewajiban untuk memberlakukan Resolusi yang dikeluarkan oleh Majelis Umum PBB. Oleh karena itu, suatu negara wajib untuk mensyaratkan sektor swasta yang

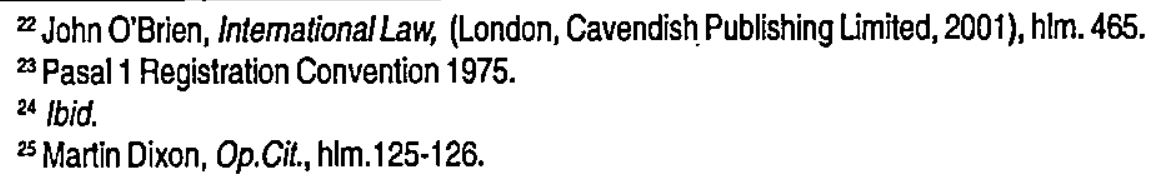


melaksanakan kegiatan komersil ruang angkasa untuk menghormati dan melaksanakan kewajiban tersebut.

Ketiga, menurut artikel VI Space Treaty, negara memiliki kewenangan untuk mengawasi kegiatan ruang angkasa yang dilakukan oleh sektor swasta. Negara yang kompeten disini ialah baik negara yang merupakan nasionalitas pihak privat company maupun negara dimana aktivitas tersebut dilaksanakan. Negara yang bertanggung jawab disini ialah the launching states.

Menurut Prof Gorove, "adalah sesuatu yang logis jika suatu aktivitas atau kepemilikan yang dimiliki oleh perusahaan swasta suatu negara menjadi tanggung jawab negara tersebut, untuk memberlakukan tanggung jawab internasional. ${ }^{26}$ Walaupun ketentuan ini bertentangan dengan suatu intepretasi yang strik terhadap liability Convention, dimana dalam konvensi ini hanya mengatur kegiatan ruang angkasa yang dilakukan oleh negara peluncur saja tanpa menyebutkan kegiatan ruang angkasa yang dilakukan oleh perusahaan swasta negara peluncur, walaupun mungkin kegiatan ruang angkasa yang dilakukan oleh perusahaan swasta diatur secara implisit. Selain itu, kalau dikaji secara komprehensif pasal VI Space Treaty memiliki kesesuaian dengan artiken IX Space Treaty" untuk memahami "Appropriate State "adalah negara yang privat companynya merupakan nasionalitasnya, maka memiliki kewajiban untuk bertanggung jawab atas privat company tersebut.

Para penulis yang sekarang lebih membedakan tanggung jawab antara dua negara yang terlibat dalam kegiatan ruang angkasa berdasarkan suatu dasar hukum yang berbeda. Pertama kekuasaan negara yang negaranya melaksanakan kegiatan peluncuran maka dia memiliki jurisdiks! berdasarkan personal jurisdiction. Sedangkan bagi perusahaan swasta yang melaksanakan peluncuran, maka negara yang memiliki jurisdiksi ialah negara dimana perusahaan tersebut memiliki nasionalitas memiliki hak untuk mengawasi dan mengontrol serta memiliki jurisdiksi.

Bagi negara yang perusahaan swastanya melaksanakan peluncuran, dengan menggunakan fasilitas asing, atau di teritorial asing, maka yurisdjksi dari negara dimana perusahaan tersebut memiliki nasionalitas tergantung kepada negara dimana peluncuran tersebut dilaksanakan, karena kewenangan untuk melaksanakan yurisdiksinya berdasarkan yurisdiksi personal hanya akan dapat dilaksanakan atas persetujuan dimana peluncuran dilaksanakan.

Namun demikian pengertian authorisasi oleh negara dimana perusahaan swasta tersebut memiliki nasionalitas dapat diartikan sebagai ijin minimum yang diperoleh dari negaranya. Sedangkan pengertian "continuing supervision" adalah sangat perlu untuk menambahkan, bahwa kegiatan ruang angkasa dan di celestial body dikecualikan dari pengawasan, karena hanya negara pendaftar yang memiliki yurisdiksi atas objek yang diluncurkan di ruang angkasa. Kekuasaan negara untuk melaksanakan yurisdiksi pada warga negaranya yang melaksanakan

${ }^{26}$ Gorove, Implication of International Space Law for Private Enterprise, (7 Annals Air \& Space Law, 1982), him. 319-321.

${ }^{27}$ Lihat ketentuan Space Treaty pasal VI dan IX. 
kegiatan ruang angkasa dapat dilaksanakan bersamaan oleh negara pendaftar. Sebagai contoh, misainya sebuah perusahaan swasta melaksanakan kegiatan ruang angkasa, negara dimana perusahaan tersebut memiliki nasionalitas dapat melaksanakan yurisdiksinya, jika saja kegiatan yang dilaksanakan tersebut bertentangan dengan hukum nasionalnya.

\section{Tanggungjawab Negara Terhadap Kegiatan Ruang Angkasa Yang Dilakukan oleh Perusahaan Swasta}

Dalam setiap sistem hukum jika terjadi pelanggaran terhadapa kewajiban secara umum akan meminculkan tanggung jawab negara. Prinsip tanggung jawab negara telah dikembangkan dalam hukum kebiasaan internasional yang meliputi aspek prosedural dan substansial. Masalah tanggung jawab negara ini akan memunculkan tiga fundamental pertanyaan. Pertama, Dalam situasi dan kondisi yang bagaimana suatu negara dapat menuntut negara lain ? Kedua, Dalam hal melakukan tindakan apa negara bertanggung jawab ? Ketiga, berdasarkan prinsip apa tanggung jawab negara ini akan dilaksanakan?28 Berkaitan dengan kegiatan ruang angkasa yang dilakukan oleh sektor swasta di suatu negara, apakah dalam hal ini kalau terjadi kerugian akibat kegiatan yang dilakukan oleh sektor swasta ini akan dapat dilimpahkan tanggung jawabnya kepada negara ?

Adapun prinsip-prinsip umum suatu tindakan yang dapat menimbulkan tanggung jawab negara berdasarkan International Law Commission's Draft Article 1 dan 2 sebagai berikut :

1. Every intentionally wrongful act of a State entails the international responsibility of that State;

2. There is an internationally wrongful act of a State when conduct concisting of an act or omission :

a. is attributable to the State under international law;

b. and constitute a breach of an international obligation of the state..$^{29}$

Berdasarkan prinsip tersebut pertama, negara bertanggung jawab atas suatu tindakan yang sengaja melanggar hukum internasional, kedua, negara melanggar kewajiban internasional. Kewajiban internasional dapat muncul dalam hukum kebiasaan internasional maupun dalam Perjanjian internasional.

Kewajiban internasional yang tertuang dalam Perjanjian Internasional, misalnya tanggung jawab negara yang diatur dalam principle 21 Stockholm Declaration on the Human Environment of 1972, yang menegaskan bahwa : "... to ensure that activities within their jurisdiction or control do not cause damage to the environment of other stetes or of beyond the limits of national jurisdiction".30 Sehubungan dengan kegiatan komersiil di ruang angkasa yang dilakukan oleh perusahaan swasta dapat ditarik suatu pengertian bahwa kegiatan komersiil ruang angkasa yang dilakukan oleh perusahaan swasta berada dalam pengawasan dan kekuasaan negara, sehingga kalau

${ }^{28}$ John O' Brean, Op.Cit, hlm. 361.

$29 \mathrm{lbid}$.

${ }^{30}$ Francisco Orrego Vicuna, state Responsibility, Liability, and Remedial Measures under International Law : New Criteria for Environmental Protection, dalam Edith Bwormn Weiss, Environmental Change and International Law, (University Press, 1992), hlm. 130-131. Lihat juga Principle 21 Stockholm Declaration. 
kegiatan tersebut menimbulkan kerugian negara lain maka akan memunculkan tanggung jawab negara.

Dengan semakin bervariasinya kegiatan yang dilakukan oleh negara dengan berbagai dampak yang signifikan baik terhadap manusia maupun terhadap lingkungan, terjadi juga pergeseran tentang penerapan prinsip tanggung jawab negara, yang masingmasing kasus berbeda-beda prinsip tangggung jawab yang diterapkannya. Ada tiga tingkat tanggung jawab negara, yang paling tradisional adalah tanggung jawab negara berdasarkan kesalahan (liability based on fault ), strict liability dan absolute liability. Adapun mengenai tanggung jawab negara dalam kegiatan ruang angkasa diatur dalam Liability Convention tahun 1972 sebagai pelaksanaan dari Space Treaty. Berdasarkan Liability Convention ada dua prinsip tanggung jawab yang diterapkan pada kegiatan ruang angkasa yaitu Labitilty based on fault dan absulute liability. ${ }^{31}$

Berdasarkan Draft State Responsibility menyatakan tentang tindakan yang dilakukan oleh warga negaranya (individu) yang tanggung jawabnya dapat dilimpahkan kepada negara kalau negara tersebut tidak melarang atau mencegah suatu tindakan yang dilakukan oleh warga negaranya, atau bahkan memfasilitasi. Ketentuan ini sesuai dengan ketentuan tanggung jawab negara yang diatur dalam pasal VI Space Treaty. ${ }^{32}$ Secara lebih jelas pelimpahan tanggung jawab individu kepada negara diatur dalam Pasal 6 dan Pasal 7 Draft state Responsibility tahun 2000 sebagai berikut :

"(6) The conduct of a person or group of persons shall be considered an act of the State under intemational law if the person or group of persons was in fact acting on the instruction of, or under the direction or control of, that state on carrying out the conduct.

(7) The conduct of a person or group of persons shall be considered an act of the State under international law if the person or group of persons was in fact exercisingelement of the governmental authority in the absent or default of the official authorities and in circumstances such as to call for the exercise of these elements of authoriry ". ${ }^{33}$

Berkaitan dengan kegiatan komersiil ruang angkasa yang dilakukan oleh perusahaan swasta di suatu negara, jelas dalam kegiatan ini negara tidak melarang, justru negara memberikan fasilitas baik itu berupa bantuan modal maupun pembuatan peraturan untuk mengatur kegiatan tersebut sebagaimana yang dilakukan di USA. ${ }^{34}$ Dengan demikian dapat disimpulkan bahwa kegiatan ruang angkasa yang dilakukan oleh perusahaan swasta di suatu negara akan memunculkan tanggung jawab negara kalau kegiatan tersebut merugikan negara lain.

Kegiatan ruang agkasa selain memberikan keuntungan bagi kehidupan manusia seperti riset ilmiah, telekomunikasi, penginderaan jarak jauh penyiaran langsung melalui satelit, tetapi juga menimbulkan dampak negatif bagi manusia.

\footnotetext{
${ }^{31}$ Liability Convention 1972.

${ }^{32}$ Space Treaty Pasal VI..$^{33}$ John O'Brien, Op.Cit., hlm.361.

${ }^{34} \mathrm{http}$ ://ast.faa.gov/about CST/ Associate Administrator for Commercial Space Transportation, diakses tanggal 24 Maret 2005.
} 
Akibat negatif dari aktivitas ruang angkasa pada umumnya lebih dari sekedar resiko kehilangan atau kerusakan objek ruang angkasa. Kegagalan peluncuran satelit ke ruang angkasa sangat berbahaya dan dapat mempengaruhi keberadaan umat manusia secara keseluruhan, karena dapat mencemari lingkungan bumi, atmosfir dan menimbulkan gangguan berat terhadap kehidupan. Oleh karena resikonya sangat besar dan berbahaya maka negaralah yang dibebani tanggungjawab internasional terhadap aktivitas komersiial ruang angkasa di negaranya, baik yang dilakukan oleh badanbadan pemerintah maupun swasta dan bukan si pelaku langsung.

Ketentuan Space Treaty pasal V! secara principil memang tidak melarang kegiatan komersiil. Selain itu dalam pasal ini juga membebankan kewajiban kepada negara untuk bertanggung jawab terhadap kegiatan ruang angkasa di negaranya tanpa membedakan apakah kegiatan tersebut dilakukan oleh negara atau oleh swasta. Sedangkan ketentuan yang lebih ketat ialah ketentuan tentang jurisdiksi negara terhadap terhadap objek-objek yang diluncurkan ke ruang angkasa, demikian juga kalau muncul tanggung jawab, maka tanggung jawab ini menjadi tanggung jawab negara.

Tanggungjawab negara sebagaimana yang diatur dalam Space Treaty pasal VII ditindak lanjuti dengan Liability Convention tahun 1972 tentang Tanggung Jawab Negara. Berdasarkan Konvensi ini negara peluncur ${ }^{35}$ bertanggung jawab secara mutlak terhadap kerugian yang diderita oleh pihak ketiga baik di udara maupun di permukaan bumi. ${ }^{36}$ Sedangkan kerugian yang diderita oleh pihak ketiga selain di dua tempat tersebut, prinsip tanggung jawab yang berlaku adalah berdasarkan kesalahan (iiability based on fault ). Dengan demikian berdasarkan Konvensi ini, negara tetap bertanggung jawab atas suatu kerugian yang disebabkan oleh kegiatan komersiil ruang angkasa yang dilakukan oleh pihak swasta. $\mathrm{Hal}$ ini tentu saja sangat mempengaruhi peraturan dalam hukum nasionalnya. Apakah suatu negara akan mengijinkan keterlibatan swasta dalam kegiatan ruang angkasa atau tidak adalah merupakan hak suatu negara, karena hal ini berkaitan dengan pertanggungjawaban negara dalam masyarakat internasional.

Adapun sebagai perwujudan tanggung jawab negara dalam kegiatan ruang angkasa terhadap kegiatan komersiil ruang angkasa yang dilakukan oleh perusahaan swasta ialah, pertama menetapkan kebijakan nasional kegiatan komersiil ruang angkasa, kedua, negara mengeluarkan peraturan nasional dan melakukan pengawasan secara efektif.

\section{Simpulan}

Kegiatan komersiil ruang angkasa yang dilakukan oleh perusahaan swasta menimbulkan permasalahan hukum tersendiri. Permasalahan hukum yang muncul ialah masalah tanggung jawab negara. Dalam hukum ruang angkasa baik yang tertuang dalam Space Treaty maupun Liability Convention tanggung jawab yang diatur adalah tanggung jawab negara bukan tanggung jawab perusahaan swasta. Sehingga masing-masing negara membuat kebijakan nasional dan

\footnotetext{
${ }^{35}$ Pasal ! ayat (c) Liability Convention

${ }^{36}$ Tanja L. Zwaan, Space Law: View of the Future, (London, Kluwer Law and Taxation Publishers, 1988),
} hlm. 14-15. 
perundang-undangan nasional dalam kegiatan komersill ruang angkasa.

Sebagai perwujudan tanggung jawab negara atas kegiatan ruang angkasa antara lain berupa kebijakan nasional negara dalam kegiatan komersil ruang angkasa, pembentukan peraturan perundang-undangan nasional dan pengawasan secara efektif kegiatan komersill oleh perusahaan swasta, pemberian ijin dengan persyaratan persyaratan khusus, misalnya adanya kewajiban penutupan asuransi pertanggung jawaban. Sehingga perusahaan swasta akan mampu untuk melaksanakan tanggung jawabnya, jika kegiatannya merugikan pihak ketiga, sekalipun dalam hubungannya dengan kerugian yang diderita oleh negara lain tetap negara yang bertanggung jawab secara internasional, atas nama perusahaan swasta di negaranya.

\section{Daftar Pustaka}

B, Nagy., 1988, "Common Heritage of Mankind: The Status of Future Generations", Proceedings 31 st Colloquium, Bangalore.

Committee and Commerce, Science and Transportation, US Senate, 1983, "Policy and Legal Issues Involved in the Coomercialization of Space".

Dixon, Martin 1996, International Law, London, Blackstone Press Limited.

Dieriks, Verschoor, 1993, An Introduction to Space Law, Boston, Kluwer Law and Taxation Publishers, hlm. 98.

Gorove,1982, Implication of Intemational Space Law for Private Enterprise, 7 Annals Air \& Space Law

L, Zwaan Tanja., 1988, Space Law : View of the Future, London, Kluwer Law and Taxation Publishers.

O'Brien, John, 2001, International Law, London, Cavendish Publishing Limited.

Sumardi, Juajir, 1996, Hukum Ruang Angkasa Suatu Pengantar, Jakarta, PT Pradnya Paramita.

Weiss, Edith Bwormn, 1992, Environmental Change and International Law, Tokyo, University Press.

Wiradipradja, E. Saefullah dan Mieke Komar Kantaatmadja (Editor) 1988, Hukum Angkasa dan Perkembangannya, Bandung, Cv Remaja Karya, hlm. 173.

Williams, 1988, The Exploitation and Use of Natural Resourcesin the New Law of the Sea and the Law of Outer Space, Proceedings of the 29th Colloquium on the Law of Outer Space.

http://ast.faa.gor/poli-legil. Associate Administrator for Commercial Space Transportation Policy and and Legislation, diakses pada tanggal 24 Maret 2005

hitp://ast.faa.gov/about CST/ Associate Administrator for Commercial Space Transportation, diakses tanggal 24 Maret 2005.

Konvensi Internasional

Liability Convention tahun 1972

Registration Convention tahun 1975

Space Treaty tahun 1967

Liability Convention tahun 1972

The Moon Agreement tahun 1979

Liability Convention tahun 1972 